\title{
Target of Improving Poverty Alleviation Trek: A Case of Bangladesh
}

\author{
Md. Amzad Hossain ${ }^{1}$ \\ ${ }^{1}$ Government Edward College, Ministry of Education, Government of Bangladesh, Bangladesh \\ Correspondence: Md. Amzad Hossain, Lecturer in Sociology, Government Edward College, Ministry of \\ Education, Government of Bangladesh, Bangladesh. Tel: 880-1717-432-645.
}

Received: May 8, 2017

doi:10.20849/ajsss.v2i2.162
Accepted: June 8, 2017

Online Published: June 27, 2017

URL: https://doi.org/10.20849/ajsss.v2i2.162

\begin{abstract}
The study aims to provide a systematic outline of Bangladesh development progress since its independence in 1971 to the present epoch regarding poverty alleviation trek. Though Bangladesh has achieved considerable progress in reducing head count poverty and poverty gap ratio but hunger poverty reduction and employment generation should be given more attention at the present time. According to MDG report last 2014; Bangladesh has made commendable progress in respect of eradication of poverty and hunger. It has sustained a GDP growth rate of 6 percent or above in recent years that has played a positive role in eradicating poverty. The main objective of the study is to investigate some important issues like poverty, inequality, unemployment scenery and social instability in the context of Bangladesh. The method of the study has been used to identify and review of Bangladesh government and UN published report analytically. The robust growth has been accompanied by corresponding improvements in several social indicators such as increased life expectancy and lower fertility rate despite having one of the world's highest population densities. This inclusive growth has resulted in impressive poverty reduction from 56.7 percent in 1991-92 to 31.5 percent in 2010; the rate of reduction being faster in the present decade than the earlier ones (MDG report last, 2014). The latest HIES 2010 data shows that the incidence of poverty has declined on an average 1.74 percentage points in Bangladesh between 2000 and 2010 against the MDG target of 1.20 percentage points. The estimated poverty headcount ratio for 2013 is 26.2 percent. Bangladesh has already met one of the indicators of target 1 by bringing down the poverty gap ratio to 6.5 against 2015 target of 8.0 (HIES Survey, 2010) .In conclusion, the challenges with regard to the dropping income disparity and the low economic involvement of women also remain as major concerns as well as reducing inequality, accelerating poverty lessening, moreover how to change the nature of the growth process should be prioritize for Bangladesh to consider sincerely.
\end{abstract}

Keywords: poverty alleviation, MDG, HIES, economic development, inequality, Bangladesh

\section{Background}

Bangladesh is a small country located in South Asia which gained its independence from Pakistan in 1971 after a bloody civil war. Bangladesh has one of the highest population densities in the world, with 155 million people living in an area of 130,170 square kilometres (World Bank, 2014). Even though Bangladesh has been experiencing weak governance, poor quality of public institutions, high levels of corruption and is frequently hit by cyclones and flooding, it has experienced economic growth and poverty reduction. It is also making progress towards achieving many of the Millennium Development Goals (MDGs) (Sukaj.Rubina 2012). 


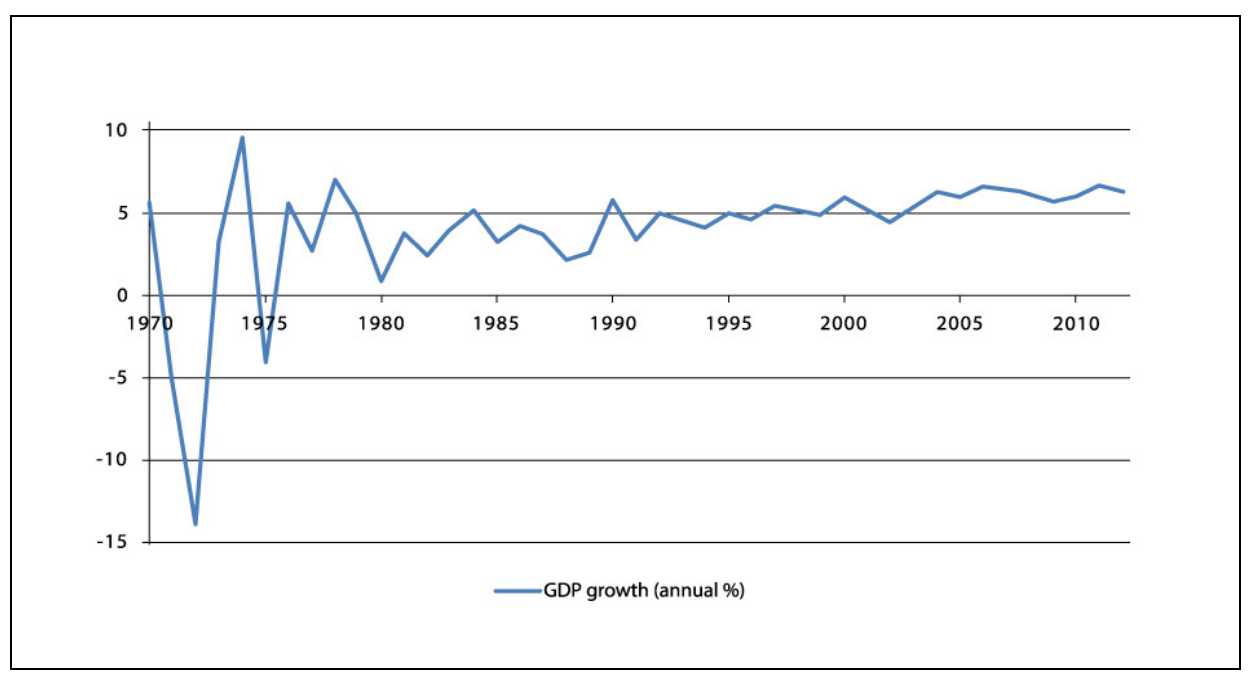

Source: Created by Sukaj.Rubina, author based on World Bank (2014).

Figure 1. GDP growth (annual, percent)

World Bank conducted a study in 2014 and said that the Liberation War in 1971 was very hard on the economy of Bangladesh and was followed by slow growth. However, in the 1980s, the economy started to grow again; though at relatively low rates (averaging 3.2 percent in real terms during 1980-1989, see World Bank, 2014). Following the liberation war, the political situation in the country was characterized by several years of political unrest and turmoil, the military taking control of the country, and assassinations of presidents. As illustrated in Figure 1, since the return of democracy in 1991, Bangladesh's economy has achieved a more steady growth rate, averaging 5.93 percent during 2000-2012. Real GDP growth reached a maxim of 6.7 percent in 2011, followed by a slightly lower, but still impressive, 6.3 percent in 2012 (World Bank, 2014).

The Household Income and Expenditure Survey (HIES) 2010 data reveals that the incidence of poverty has been declining at an annual rate of 2.47 percent in Bangladesh during 1991-92 to 2010 against the MDG target of 2.12 percent. Bangladesh has already met one of the indicators of target-1 by bringing down the poverty gap ratio to 6.5, against the MDG target of 8.0 in 2015. Since the trend of sustained GDP growth is continuing, the MDG target of halving the population living under the poverty line (from $56.7 \%$ to $29 \%$ ) has already been achieved in 2012 (The Household Income and Expenditure Survey (HIES) 2010). The robust growth has been accompanied by corresponding improvements in several social indicators such as increased life expectancy and lower fertility rate. The inclusive growth has resulted in significant poverty reduction from 56.7 percent in 1991-92 to 31.5 percent in 2010; the rate of reduction was faster in the present decade (2001-2010) than in the earlier decade (1991-2000) (MDG, 2014).

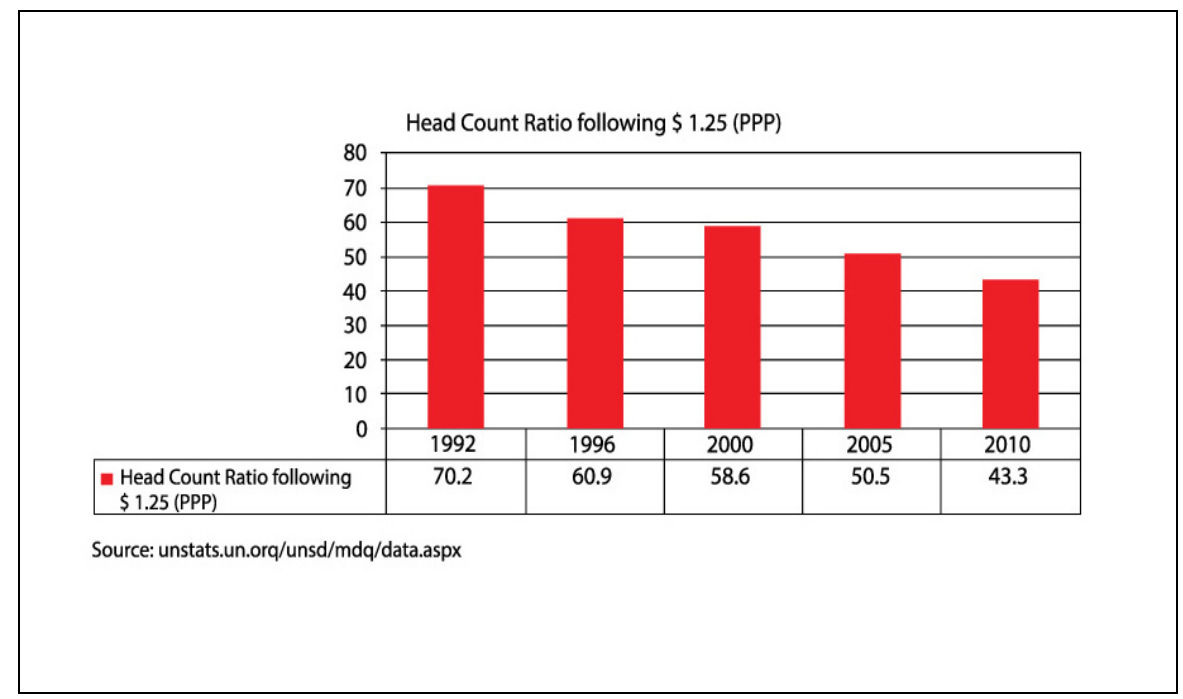

Figure 2. Head count ratio following $\$ 1.25$ (PPP) 
M. Syeed Ahamed and Mohammad Ehsan conducted a study on labour market perspective in 2005 and found that Bangladesh's labour force has experienced a significant structural change at the beginning of 1990s and continued during the subsequent years. When Bangladesh began to respond to the globalisation process with market liberalisation, a large population migration was observed from rural to urban areas for gainful employment and other economic activities. During this period, agriculture as source of income of the household at the national level decreased from 33.4 per cent in 1991-92 to 18.0 per cent in 2000. In contrast the share of business and commerce in national house hold income increased from 14.8 per cent in 1991-92 to 25.9 per cent in 2000. About 6 per cent of the total labour force shifted from agriculture to other service related jobs during this period. Export oriented industries; especially the clothing sector has been a major contributor to this shift which took place under the preferential market access, largely within the ambit of the Multi-Fibre Arrangement (MFA). However, fear of retrenchment following the phasing out of MFA quota has now become a challenge for this migrated labour force (M. Syeed Ahamed and Mohammad Ehsan.2005).

\section{Objectives}

(a) To identify about a systematic overview of Bangladesh's development progress

(b) To investigate some important issues like poverty, inequality and unemployment scenery in the context of Bangladesh.

\section{Material \& Methods}

In this paper, the researcher mainly focuses on Bangladesh's developmental progress since gaining its independence in1971. During the last five years, the country experienced close to an annual 6 percent growth rate in real GDP, continuing its path of growth despite the recent world financial and economic crisis. Bangladesh has also made serious progress with achieving the Millennium Development Goals (MDGs). Following a review of Bangladesh's recent progress by secondary data sources (Such as-BBS, World Bank, MDGs Report) the paper then take the attention on three priority areas - poverty, inequality, unemployment and social instability where the government needs to focus on in order to make further progress in Bangladesh's development.

\section{Theoretical View}

The theory of a "culture of poverty" was created by the anthropologist Oscar Lewis in his 1959 book, Five Families: Mexican Case Studies in the Culture of Poverty. The culture of poverty theory states that living in conditions of pervasive poverty will lead to the development of a culture or subculture adapted to those conditions (www.encyclopedia.com). This culture is characterized by pervasive feelings of helplessness, dependency, marginality, and powerlessness. Furthermore, Lewis described individuals living within a culture of poverty as having little or no sense of history and therefore lacking the knowledge to alleviate their own conditions through collective action, instead focusing solely on their own troubles. Thus, for Lewis, the imposition of poverty on a population was the structural cause of the development of a culture of poverty, which then becomes autonomous, as behaviors and attitudes developed within a culture of poverty get passed down to subsequent generations through socialization processes (Lewis, Oscar. 1959). The settlement house founders in Chicago disagreed with the theory that poverty was entirely a function of race and ethnicity. In the 1890's, the Social Survey Movement described the social economy of the era. Led by staff at Hull House in Chicago, surveys such as The Hull House Papers, The Philadelphia Negro and the Pittsburgh Social Survey described poverty conditions in much broader terms than had been done in the past. These studies started the tradition of showing the linkages between race, gender and social class as fundamental drivers of poverty. They described the deficiencies of poor people, but also documented the operations of industrial capitalism with the labor exploitation, low wages, and unemployment, and the effects of gender based divisions of labor. At the turn of the Century, W.E.B. Du Bois listed the four major causes of poverty as being (1) slavery, which produced a deficit of skills, education and morality, (2) immigration of large number of people from other cultures, and frequent migration of people within the U.S. which often meant people were not tied into the local social networks, (3) rapid industrial change which made a large number of jobs obsolete every day, and (4) racial discrimination. (Even today, we could use nothing but his theories and have an excellent basis for anti-poverty work! Du Bois described the social mechanisms and effects of racial discrimination. In 1911, he was one of the founders the NAACP (Master jim, 2002). In The German Ideology Marx argued that social relations between people are determined by production. The various institutions of society can only be understood as developing out of this core, productive interaction. His argument applies as much to women's oppression as to any other aspect of capitalist society. Marx's proposition "men make their own history, but they do not make it under circumstances chosen by themselves", sums up the interaction we must look for between the ideas women and men use to 
justify their actions and responses to social events and the material and economic circumstances in which they operate. This differs radically from the theoretical framework of patriarchy theory. The most common versions take two forms. There are those like Juliet Mitchell who see patriarchy in psychological and ideological terms: "We are dealing with two autonomous areas, the economic mode of capitalism and the ideological mode of patriarchy." If you make such a distinction between the economic and ideological, then you cannot explain anything about the development of society. Why do some ideas dominate? And why do some dominant ideas change? (Sandra Bloodworth, 1990). Marx narrated that "The fact is ... that definite individuals who are productively active in a definite way enter into these definite social and political relations. Empirical observation must in each separate instance bring out empirically, and without any mystification and speculation, the connection of the social and political structure with production. The social structure and the state are continually evolving out of the life-process of definite individuals, however, of these individuals, not as they appear in their own or other people's imagination, but as they actually are, i.e., as they act, produce materially, and hence as they work under definite material limits, presuppositions and conditions independent of their will" (Marx. Karl 1976). On the other hand, The theory of patriarchy, which says that there is a fundamental division between men and women from which men gain power, is accepted without question today by most of the left (Intl Socialist Conference, 1990) The theory was developed by feminists such as Juliet Mitchell and Miriam Dixson who, in her book The Real Matilda (Miriam.Dixin,1990) was inclined to blame Irish working class men for women's oppression, using the theory of patriarchy as the basis for her argument. Anne Summers helped to popularise the ideas in her book Damned Whores and God's Police in the early seventies. She wrote "Women are expected to be socially dependent and physically passive because this state is claimed to be necessary for their maternal role. In fact it is because it enhances the power of men. (Summers Anne, 1976)

\section{Defining of Poverty}

The absolute notion of poverty (or at any rate, the subsistence definition associated with it) has been heavily criticised by advocates of 'relative' approaches to the concept of poverty. However, subsistence definitions of poverty are far from extinct. New Right thinkers from the late-1970s onwards have adopted absolute definitions of poverty. For example: 'A family is poor if it cannot afford to eat ... By any absolute standards there is very little poverty in Britain today' (Joseph, 1976). The concept of 'absolute' poverty refers to poverty that exists independently of any reference group. It does not depend on the general living standards of the society in which it is conceived and nor does it vary over time (Alcock, 1993). The concept of 'absolute' poverty and its definition as some kind of minimum subsistence level is strongly associated with the late nineteenth-century British social reformers Charles Booth and Seebohm Rowntree. To be poor was to be unable to attain those things necessary for survival. Rowntree defines his 'primary poverty' thus: 'Families whose total earnings are insufficient to obtain the minimum necessaries for the maintenance of merely physical efficiency' (Rowntree, 1901) On the other hand Townsend said that "Individuals, families and groups in the population can be said to be in poverty when they lack the resources to obtain the types of diet, participate in the activities and have the living conditions which are customary, or at least widely encouraged or approved, in societies to which they belong. Their resources are so seriously below those commanded by the average family or individual that they are in effect excluded from ordinary living patterns, customs and activities". (Townsend, 1979, p.31) Concepts of poverty in industrialised nations have developed over the years from 'absolute' concepts which are frequently defined in terms of minimum subsistence levels, to 'relative' concepts which relate poverty to notions of exclusion from participation in 'mainstream' society (Michael. et al, 2004). In Britain, critics of this definition have been concerned that the notion of 'relative poverty' might mean that some groups of people will always be 'poor' compared to others, as there will never be absolute equality (Sen, 1983). It is clearly a perversion of the notion of poverty for it to become synonymous with inequality (although the two are strongly and inextricably linked). For example, in a world where everyone owns two Rolls Royces a person who only owned one would not be poor. However, Townsend is careful to elucidate that if certain conditions of 'normal' participation are met, then those able to participate are not in poverty (Michael. et al, 2004).

This 'scientific' concept of poverty can be made universally applicable by using the broader concept of resources instead of just monetary income. It can then be applied in developing countries where barter and income in kind' can be as important as cash income. Poverty can then be defined as the point at which resources are so seriously below those commanded by the average individual or family that the poor are, in effect, excluded from ordinary living patterns, customs and activities. As resources for any individual or family are diminished, there is a point at which there occurs a sudden withdrawal from participation in the customs and activities sanctioned by the culture. The point at which withdrawal escalates disproportionately to falling resources can be defined as the poverty line or threshold (Townsend, 1979; Townsend and Gordon, 1989). "Absolute poverty is claimed to be an 
objective, even a scientific notion" (Alcock, 1993 p68) but in fact even the earliest subsistence definitions can be shown to contain some element of 'relativity'; that is, including some items in their definition of poverty that are not strictly nutritional necessities. Alcock (1993 p70) rightly points out that Rowntree included tea as a necessity in his first poverty study despite it being of negligible nutritional value. Rowntree therefore departed from a subsistence definition of poverty by recognising that tea was (and perhaps still is) viewed as a necessity in British society. By the time of his 1936 study Rowntree had included owning a radio and being able to buy a daily newspaper as necessities, tacitly accepting that what it is to be poor changes as society changes. In Britain, critics of this definition have been concerned that the notion of 'relative poverty' might mean that some groups of people will always be 'poor' compared to others, as there will never be absolute equality (Sen, 1983).

Poverty is a widely used and understood concept but its definition is highly contested. The term 'poverty' can be considered to have a cluster of different overlapping meanings depending on what subject area or discourse is being examined (Gordon and Spicker, 1998). For example, poverty, like evolution or health, is both a scientific and a moral concept. Many of the problems of measuring poverty arise because the moral and scientific concepts are often confused. In scientific terms, a person or household in Britain is 'poor' when they have both a low standard of living and a low income. They are not poor if they have a low income and a reasonable standard of living or if they have a low standard of living but a high income. Both low income and low standard of living can only be accurately measured relative to the norms of the person's or household's society.

\section{Measurement of Poverty in Bangladesh}

The economic review of Bangladesh depicts that the first Household Expenditure Survey (HES) in Bangladesh was carried out in FY 1973-74 and it was followed by a number of HESs (The economic review, 2013). The latest HESs was done in 2010. HESs carried out up to FY 1991-92 used Food Energy Intake (FEI) and Direct Calorie Intake (DCI) methods in order to measure the incidence of income poverty. A person having daily calorie intake of less than 2122 kilo-calories used to be considered to be in absolute poverty and 1805 kilo-calories in hard-core poverty. In the HES conducted in 1995-1996, the BBS for the first time adopted the Cost of Basic Needs (CBN) method. Similarly, in the Household Income and Expenditure Surveys (HIES) of 2000 and 2005 and 2010, CBN method was used. With this method, non-food consumption is also considered for constructing poverty index.

\section{Conceptual Framework Causes of Poverty}

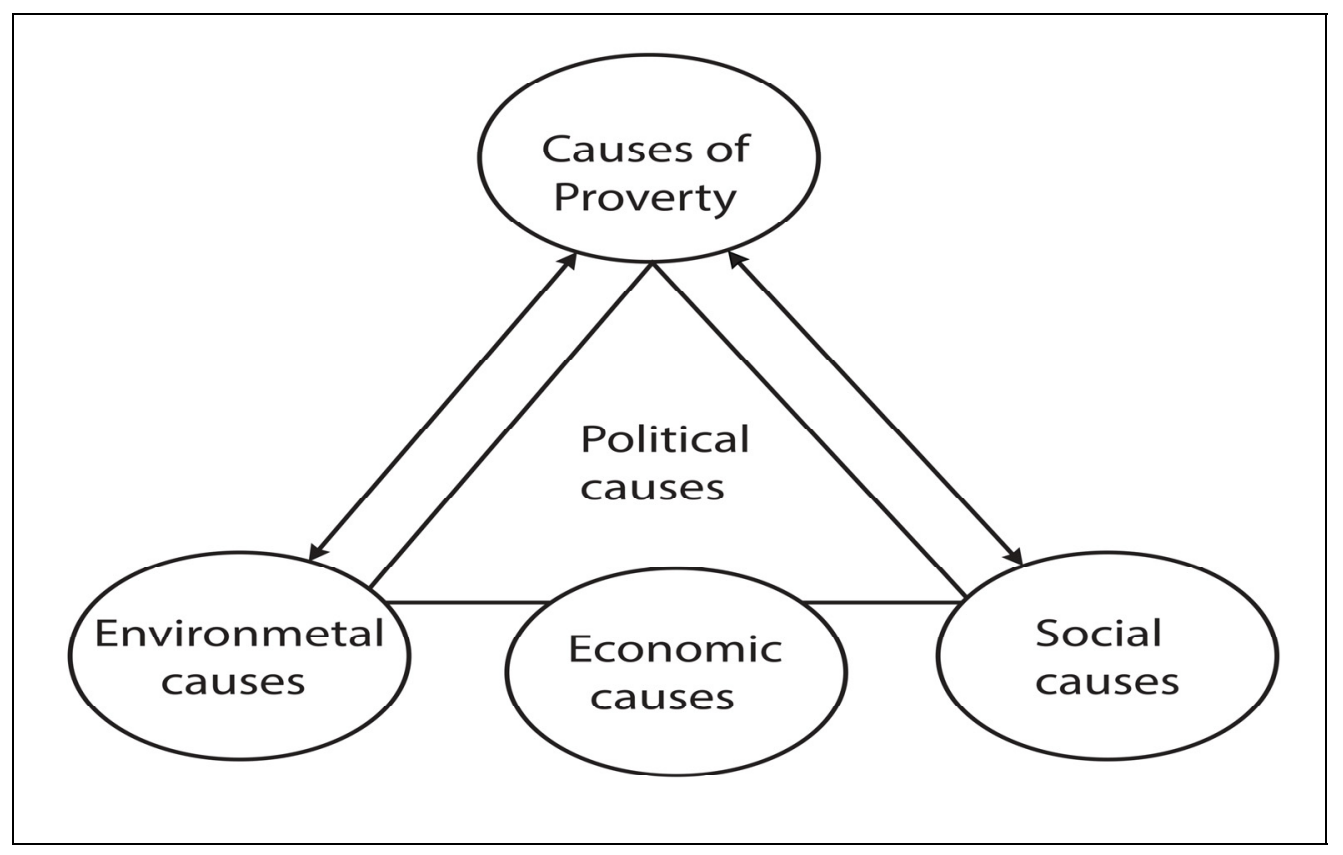

\section{Poverty Trek in Bangladesh}

This BBS uses the cost-of-basic-needs (CBN) method for estimating poverty, whereby any household with real per capita expenditure below a given poverty line is considered as poor (BBS, 2002). Analysis of various 
Household Expenditure Surveys (HES) conducted by BBS during the decade shows that the incidence of poverty, as measured by both the upper and lower CBN poverty lines, has fallen considerably following table. In 2000,50 percent of the country's population was poor (as measured by the upper poverty line), compared to 59 percent in 1991-92. Similarly, the extreme poverty rate (below the lower poverty line) declined from 43 percent in 1991-92 to 34 percent in 2000. Thus, according to both measures, the incidence of poverty in Bangladesh declined by about 9 percentage points over the nine-year period.

\begin{tabular}{|c|c|c|c|c|c|c|}
\hline & \multicolumn{3}{|c|}{ Upper Poverty Line } & \multicolumn{3}{|c|}{ Lower Poverty Line } \\
\hline & 1991-92 & $1995-96$ & 2000 & $1991-92$ & $1995-96$ & 2000 \\
\hline \multicolumn{7}{|c|}{ HEADCOUNT RATE $\left(\mathrm{P}_{0}\right)$ : } \\
\hline National & 58.8 & 51.0 & 49.8 & 42.7 & 34.4 & 33.7 \\
\hline Urban & 44.9 & 29.4 & 36.6 & 23.3 & 13.7 & 19.1 \\
\hline Rural & 61.2 & 55.2 & 53.0 & 46.0 & 38.5 & 37.4 \\
\hline \multicolumn{7}{|c|}{ POVERTY GAP $\left(\mathrm{P}_{1}\right)$ : } \\
\hline National & 17.2 & 13.3 & 12.9 & 10.7 & 7.6 & 7.3 \\
\hline Urban & 12.0 & 7.2 & 9.5 & 4.9 & 2.6 & 3.8 \\
\hline Rural & 18.1 & 14.5 & 13.8 & 11.7 & 8.6 & 8.2 \\
\hline \multicolumn{7}{|c|}{ SQUARED POVERTY GAP $\left(\mathrm{P}_{2}\right)$ : } \\
\hline National & 6.8 & 4.8 & 4.6 & 3.9 & 2.5 & 2.3 \\
\hline Urban & 4.4 & 2.5 & 3.4 & 1.5 & 0.7 & 1.2 \\
\hline Rural & 7.2 & 5.3 & 4.9 & 4.3 & 2.8 & 2.6 \\
\hline
\end{tabular}

Source: BBS and World Bank staff estimates.

Figure 3. Cost-Of-Basic-Needs (CBN)

The report (BBS, 2002) also explains that the poverty gap (P1) estimates how far below the poverty line the poor are on average as a proportion of that line. The squared poverty gap (P2) takes into account not only the distance separating the poor from the poverty line, but also inequality among the poor. Trends in these measures broadly mirror observed changes in the headcount rates, suggesting that even among the poor, a greater share of people are now closer to the poverty line than they were at the beginning of the decade. It is also worth noting that these distributionally sensitive poverty measures (P1 and P2) declined relatively more rapidly that the headcount rate (BBS, 2002).

Professor. S. Aminul Islam showed (2004) in study that the estimated level of rural poverty of the country after its independence varied from 55.7 percent to as high as 82.9 percent, the latter being the official figure. Further he said, the period between 1963-64 and 1976-77 saw a major surge in poverty. During this period the number of hard core poor increased from a negligible figure to 45 million or 60 percent of the rural population. The hard-core poor made up over 40 percent of the urban population in the middle of 1970s, although they were rarely found in early 1960s. (Vylder, 1982. Table shows that there has been a slow reduction in income poverty, which could be as high as 83 percent, but most probably 74 percent (Sen, 2003) in 1973-74. 


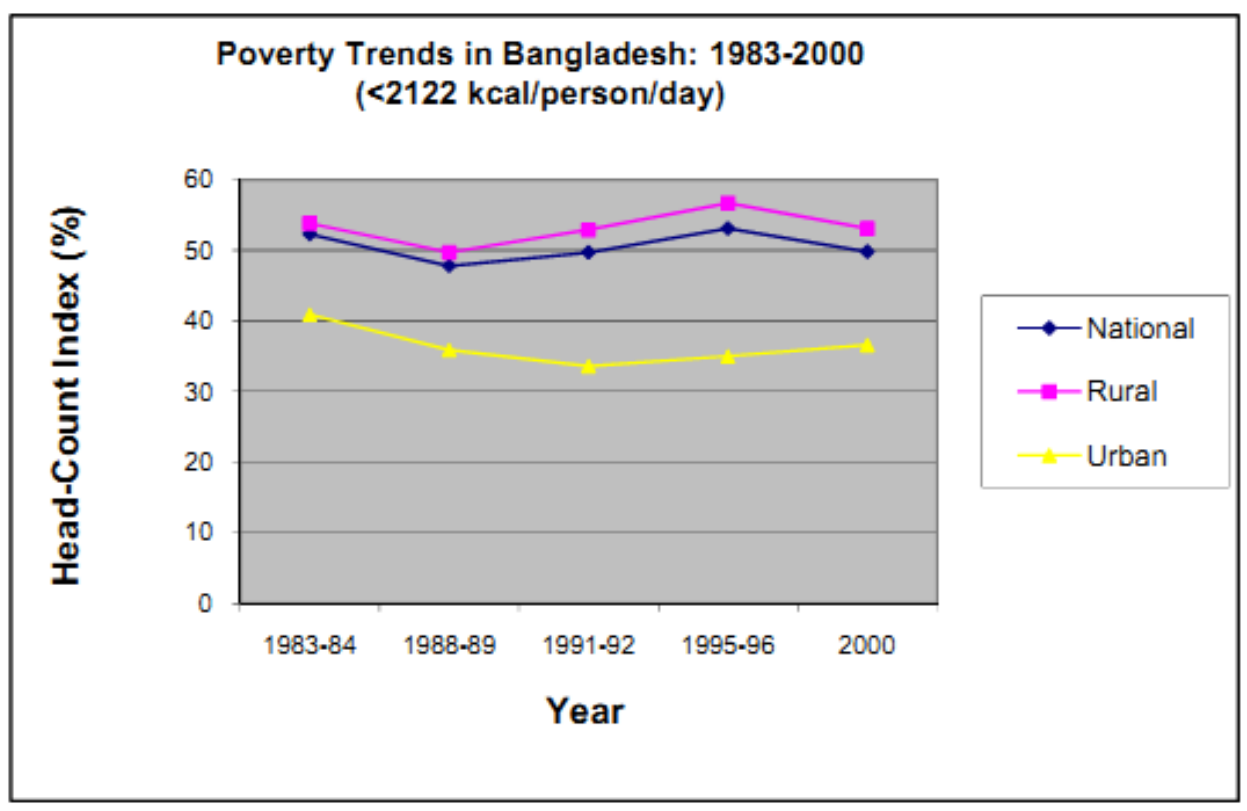

Source-BBS, 2002

Figure 4. Poverty trends in Bangladesh

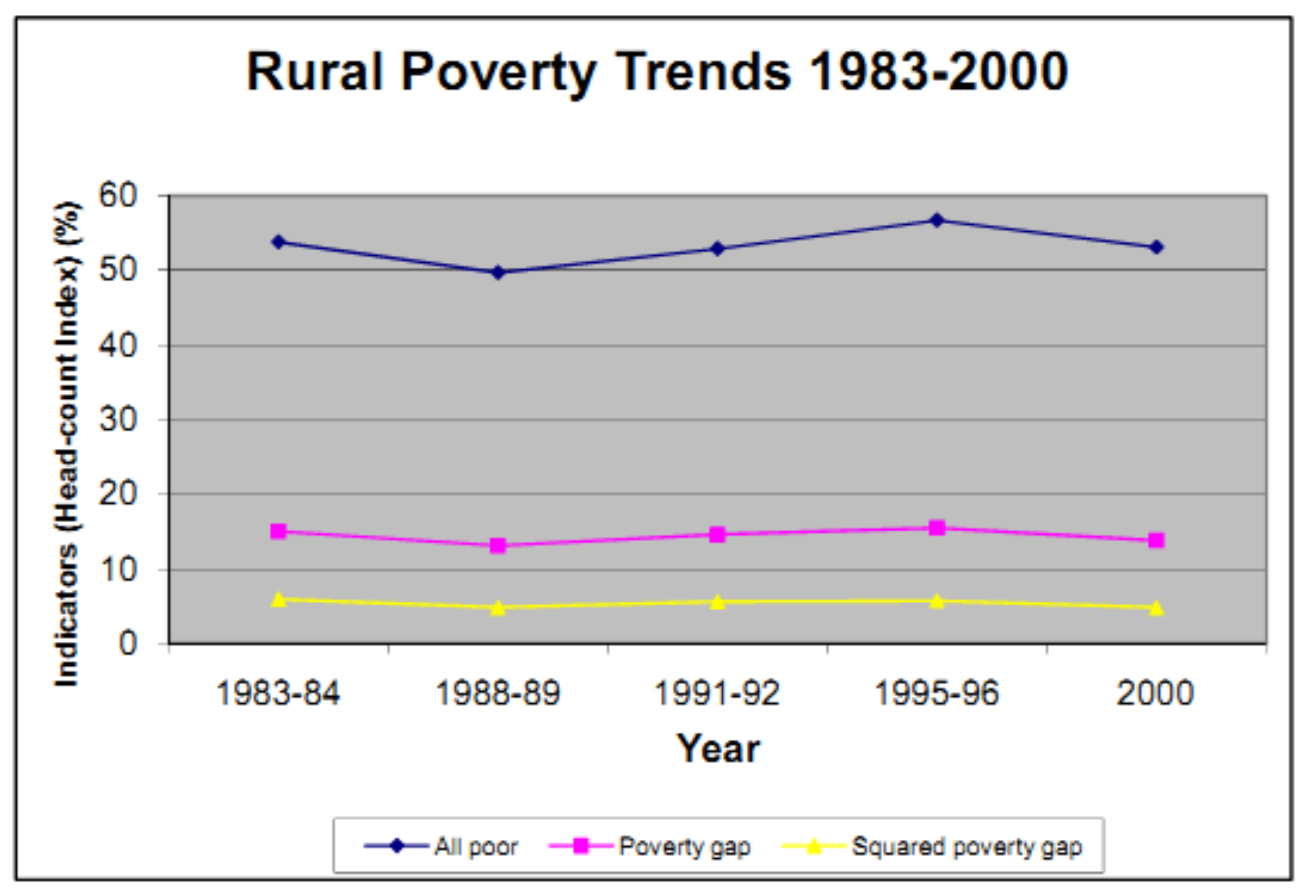

Source: HIES 2000

Figure 5. Rural poverty trends 1983-2000

The hard-core or extreme poverty showed a similarly slow decrease - it went down by only 3.4 percent over a decade from 1985-86.In 2000 it stood at 25 percent of the population (BBS, 2002).According to Sen (2003), The rural poverty appears to have declined more rapidly during 1970s and early 1980 s when it went down to about 54 percent. There was a slight decrease of rural poverty during the second half of 1980s. But it went up to about 53 percent in 1991-92 - to the level of the first half of earlier decade. But BBS charts a steady decline of rural poverty from 61.2 percent in 1991-92 to 53 percent in 2000. The urban poverty fell from 44.9 percent to 29.4 percent in 1995-96 and then registered a slight increase to 36.6 percent at the dawn of a new millennium. The 
above figure shows decline in rural poverty in terms of poverty gap and squared gap. Over the 1990s the poverty gap in the countryside declined by 2.8 percent, which was higher than urban areas. In the similar way the squared poverty gap also declined over the same period by 3.8 percent (GOB, 2002).

The millennium development goals 2012 stated that the decline in headcount ratio was greater than population growth during 2005-2010 period which led to a decline in the absolute number of the poor people. The size of the population below the upper poverty and the lower poverty lines declined by nearly 8.58 million and 8.61 million respectively during the period. The level and distribution of consumption among the poor improved as well, as is evident from reductions in the poverty gap and squared poverty gap measures by 28 percent and 31 percent respectively. Real per capita consumption expenditure during the 2005-2010 period increased at an average annual rate of 16.9 percent, with a higher rate of increase in rural areas as compared with the urban areas. This shows that the economic conditions and incomes of the rural people, especially the poor, have improved significantly as a result of the pro-poor and pro-rural policies of the government (MDG-Bangladesh, 2012).

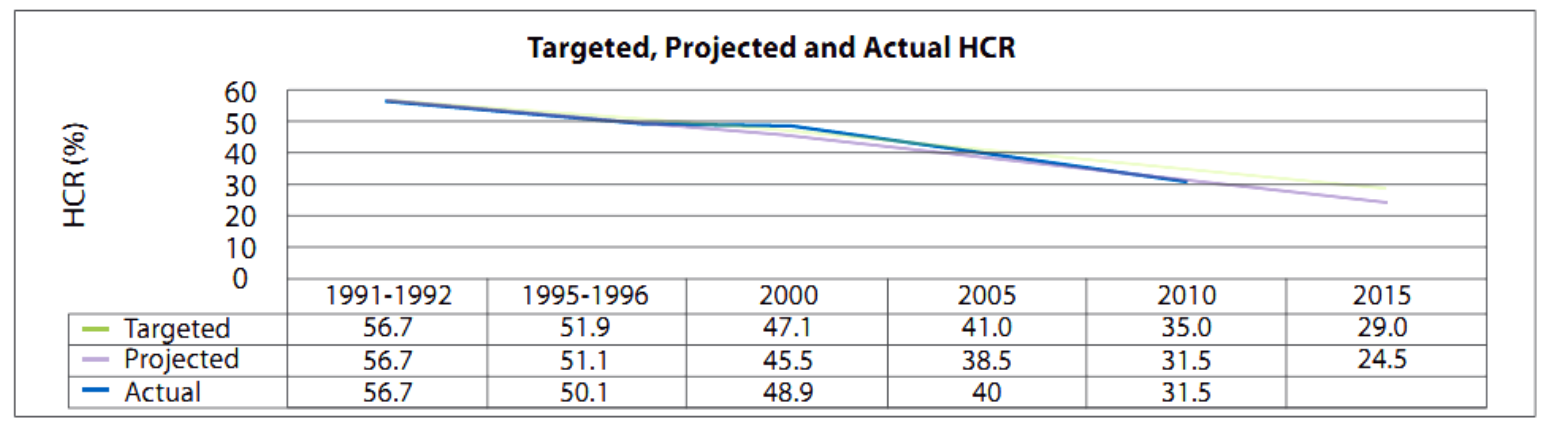

Source: Projection is made based on various rounds of HIES data of BBS

Figure 6. Targeted, projected and actual HCR

The remarkable progress in respect of eradication of poverty was largely possible due to changes in population structure, increase in labour income, improved infrastructural and telecommunication connectivity, internal migration and government's targeted safety net programs. Using the long-term decline in poverty incidence between 2000 and 2010 the value of the growth elasticity of poverty turns out to be 0.76 . Based on this value, the head count ratio in the terminal year of MDGs is estimated to be 24.5 percent. Inclusive and robust growth has resulted in an impressive poverty reduction at an annual rate of 2.47 percent in Bangladesh during the 1992 to 2010 period. The rate of poverty reduction has been faster in the present decade as compared with the previous ones.

The rate of income poverty (measured by CBN considering upper poverty line) declined from 48.9 percent to 40.0 percent during the period from 2000 to 2005 . The compound poverty reduction rate per year is recorded at 3.9 percent. But the rate of reduction of poverty is higher in urban areas (yearly rate 4.2 ). On the other hand, the rate of income poverty declined from 40.0 percent to 31.5 percent during the period from 2005 to 2010 . The compound poverty reduction rate per year is recorded at 4.67 percent. Here, also the rate of reduction of poverty is higher in urban areas (yearly rate 4.28 percent). The depth (measured by poverty gap) and severity (measured by squared poverty gap) of poverty between 2000 and 2005 declined at higher rate in urban areas than rural areas. The trends of poverty are shown in the following table: 


\begin{tabular}{|c|c|c|c|c|c|}
\hline \multirow[b]{3}{*}{ Year } & \multirow{3}{*}{2010} & \multicolumn{2}{|c|}{ Annual Change } & & \multirow[t]{2}{*}{ Annual Change } \\
\hline & & 2005 & & 2000 & \\
\hline & & \multicolumn{2}{|c|}{2005 to 2010} & & 2000 to 2005 \\
\hline \multicolumn{6}{|c|}{ Head Count Index } \\
\hline National & 31.5 & 40.0 & -4.67 & 48.9 & -3.9 \\
\hline Urban & 21.3 & 28.4 & -4.28 & 35.2 & -4.2 \\
\hline Rural & 35.2 & 43.8 & -5.59 & 52.3 & -3.5 \\
\hline \multicolumn{6}{|c|}{ Poverty Gap } \\
\hline National & 6.5 & 9.0 & -6.30 & 12.8 & -6.80 \\
\hline Urban & 4.3 & 6.5 & -7.93 & 9.1 & -6.51 \\
\hline Rural & 7.4 & 9.8 & -5.46 & 13.7 & -6.48 \\
\hline \multicolumn{6}{|c|}{ Squared Poverty Gap } \\
\hline National & 2.0 & 2.9 & -7.16 & 4.6 & -8.81 \\
\hline Urban & 1.3 & 2.1 & -9.15 & 3.3 & -8.64 \\
\hline Rural & 2.2 & 3.1 & -6.63 & 4.9 & -8.75 \\
\hline
\end{tabular}

Source: Household Income and Expenditure Surveys (HIES), 2010

Figure 7. Trend of income poverty 
Poverty alleviation mechanism of Bangladesh:

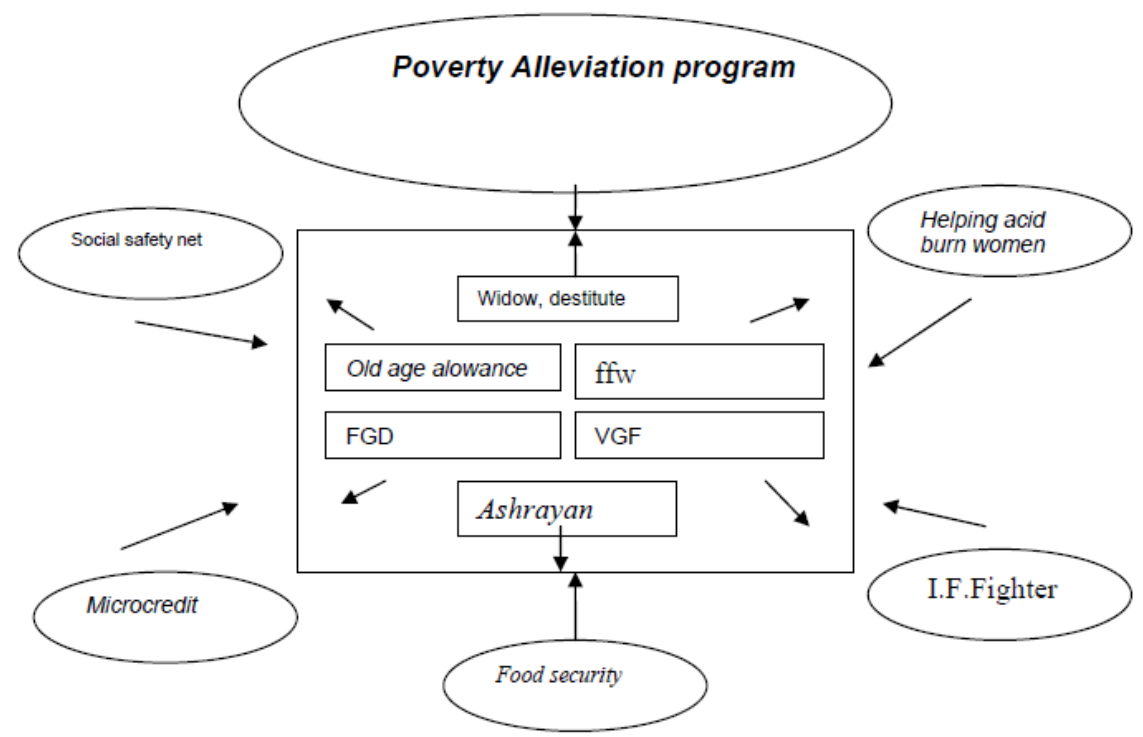

Figure 8. The fundamental poverty mechanism systems in Bangladesh

\section{Social Inequality}

The Millennium Development Goal 2012 depicts that creation of opportunities for women labour force remains the major bottleneck for wage employment for women in the non-agricultural sector with an exception of the garments industry. The participation of labour force in mainstream economic activities by gender is shown in Table 4.1. Several features are worth reporting. First, the share of women in wage employment in agricultural and non-agricultural sectors shows contrasting trend over the last two decades. While the share of the former (women in wage employment in agricultural sector) has increased between 1990 and 2005 (from 25.5 percent to 66.5 percent), the share of the latter (women in wage employment in non-agricultural sector) has declined (from 19.1 percent to 14.6 percent) as reported earlier. Between 2005 and 2010, however, while the share of the former has declined (from 66.5 percent to 40.8 percent) the share of the latter has increased (from 14.6 percent to 19.9 percent). Second, while the share of women in wage employment in agricultural sector has been higher than that in non-agricultural sector over the entire 1990-2010 period, the gap between the two has significantly increased between 1990 and 2005 but declined thereafter (between 2005 and 2010). Third, while labour force participation rate of female has steadily increased over the last two decades, that of male, although much higher than female, has displayed fluctuation between 1990 and 2010. Finally, unemployment rate of female has steadily declined, while that of male, although lower than that of female, fluctuated somewhat over the last two decades. What is encouraging is that the gap in unemployment rate between male and female has narrowed down over the years (MDG, 2012).

\begin{tabular}{|c|l|l|c|c|c|}
\hline No & \multicolumn{1}{|c|}{ Indicator } & Gender & 1990 & 2005 & 2010 \\
\hline 1 & $\begin{array}{l}\text { Share of women in wage employment } \\
\text { in agricultural sector }\end{array}$ & Female & 45.50 & 66.54 & 40.84 \\
\hline 2 & $\begin{array}{l}\text { Share of women in wage employment } \\
\text { in non-agricultural sector }\end{array}$ & Female & 19.10 & 14.60 & 19.87 \\
\hline \multirow{2}{*}{3} & Labour force participation rate & Female & 23.90 & 29.20 & 36.00 \\
\cline { 2 - 6 } 4 & Male & 84.00 & 86.80 & 82.50 \\
\hline \multirow{2}{*}{4} & Female & 7.80 & 7.04 & 5.80 \\
\cline { 3 - 6 } & Male & 3.40 & 3.35 & 4.10 \\
\hline
\end{tabular}

Source: Gender Compendium of Bangladesh 2009,BBS and LFS 2010,BBS

Figure 9. Participation of labour in mainstream economic activities: 1990-2010 
The mainstream argues that sustained and equitable economic growth inevitably leads to poverty reduction. There is widespread concern that economic growth has not been shared fairly, and that the current economic crisis further widens the gap between the rich and poor. In Bangladesh, the number of people living in poverty has increased due to rising disparities in the distribution of resources within the country. Uneven growth pattern has been proved as an obstacle in reducing poverty at a faster rate and has been shown to be harmful to growth. As such it is important to address the inequality issues for effective and faster reduction of poverty.

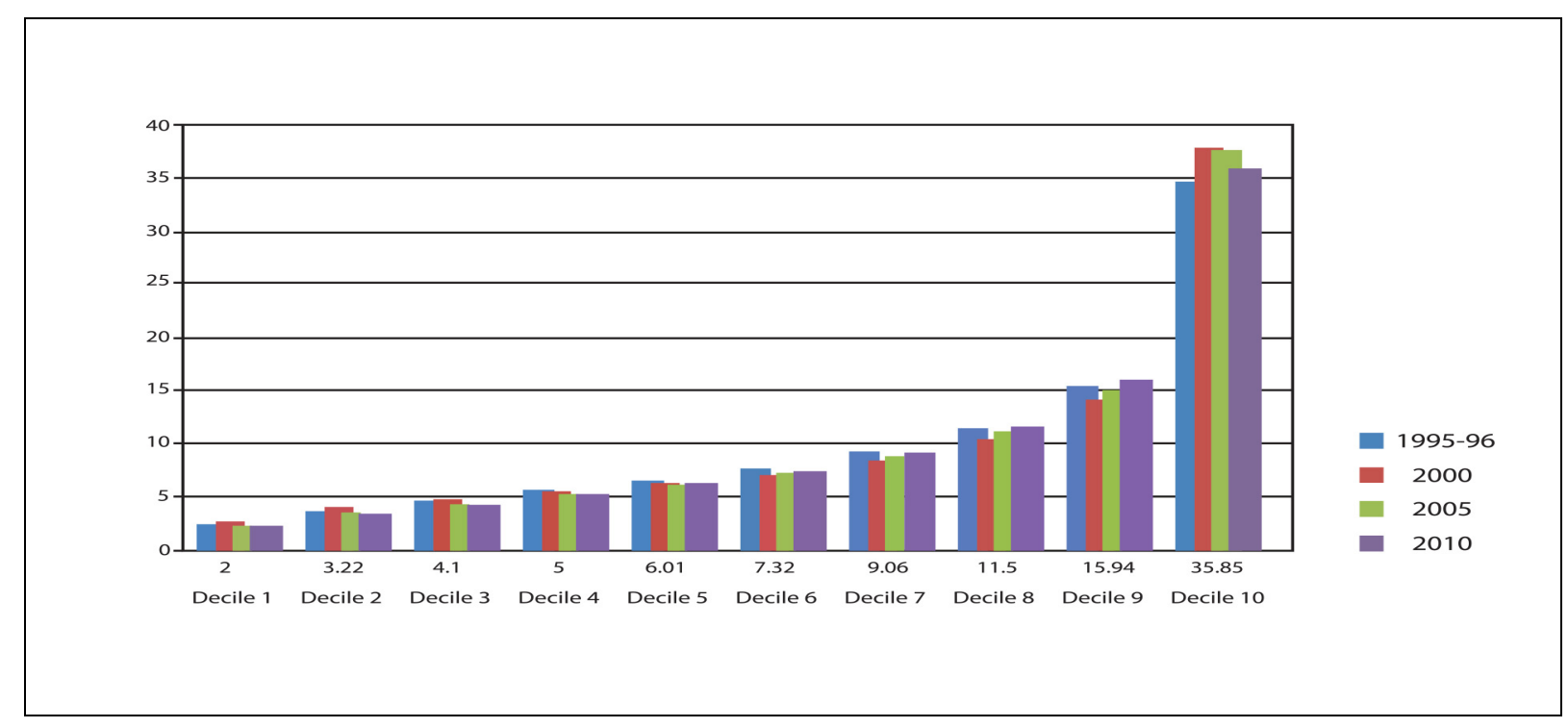

Figure 10. Percentage share of household income by decile group (Data source: HIES)

Source: HIES 2010

Decile groups from the figure 4 shows the pattern of distribution of income from percentage share of income of households. It is clear from the figure that the gap between the poorest of the poor (bottom 5\%) and the richest of the rich (top 5\%) is extremely high. In HIES 2010, the income accruing to top 5\% of the household was $24.61 \%$, whereas, the same was $0.78 \%$ for the bottom $5 \%$ household. In 2005 , income accruing to top 5 percent of the households was $26.93 \%$, where the same was $0.77 \%$ for the bottom $5 \%$. It slightly increased from $0.77 \%$ to $0.78 \%$ in 2010 . On the contrary, the share of income of the top $5 \%$ decreased from $26.93 \%$ to $24.61 \%$ over the same period indicating redistribution of income in favour of the mid-level. In 2000, income accruing to top 5 percent of the households was $28.34 \%$, where the same was $0.93 \%$ for the bottom $5 \%$. In $1995-96$, income accruing to top 5 percent of the households was $23.62 \%$, where the same was $0.88 \%$ for the bottom $5 \%$. (HIES, 2010). Figure 4 provides a clear image of the overview of inequality situation in Bangladesh.

The MDG 2012 report also assumed the situation of women empowerment and gender equality appears promising when one looks at the share of women in the highest policy making elected body-the National Parliament. During the last four governments of parliamentary democracy, women's participation in the Parliament was 12.7 percent in 1991-95; and 13 percent, 12.4 percent, 18.6 percent and 20.0 percent in 1996-2000, 2001-06, 2008 and 2012 respectively. In the current Parliament, the share of reserved seats for women has also been increased from 45 to 50. Moreover, the current Parliament has got 20 directly elected women Parliamentarians. The present government has also the highest number of women members (six in total) in the cabinet including the Prime Minister. The Speaker of the National Parliament is now a woman as well. 


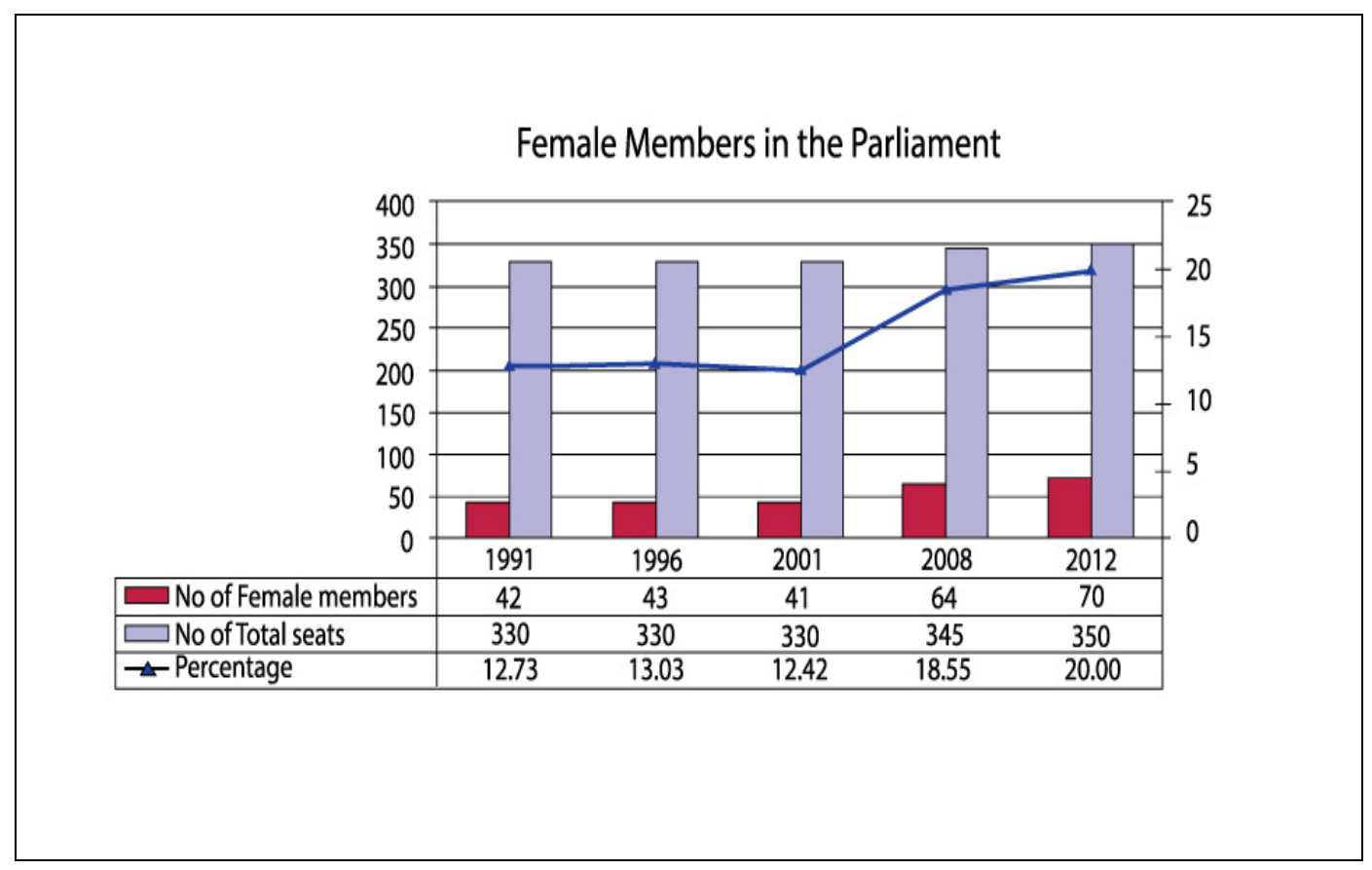

Figure 11. Female members in the parliament

Source: MDG Report, 2014.

Gini co-efficient is an instrument to measure inequality. This is the most popular composite indicator that summarizes the extent of concentration (inequality) of household income. Gini co-efficient can vary between ' 0 ' and ' 1 '. The ' 1 ' is the most unequal state and the ' 0 ' is the most equal state. At national level, the Gini co-efficient of income has increased from 0.432 in 1995-96 to 0.451 in 2000 , which has further increased to 0.467 in 2005 but decreased to 0.458 in 2010 from 0.467 in 2005. Gini co-efficient of income has increased from 0.385 in 1995-96 to 0.393 in 2000, which again increased to 0.428 in 2005 and further increased to 0.430 in 2010 at rural area, whereas for urban area it increases from 0.444 in 1995-96 to 0.497 in 2000 and remain same between 2000 and 2005 and again decreased from 0.497 to 0.452 in 2010 (HIES, 2000, 2005 and 2010). The Gini co-efficient of income has decreased at national and urban level over the last five years (2005 to 2010) while it has slightly increased in rural areas during the same time. Table 3 provides the Gini co-efficient of income inequality data for Bangladesh since 19995-96 to 2010. The data shows that inequality situation is better in rural area than in urban and at national level.

\begin{tabular}{lcccccc}
\hline Year & \multicolumn{3}{c}{$\mathbf{1 9 9 5 - 9 6}$} & \multicolumn{2}{c}{$\mathbf{2 0 1 0}$} \\
\hline GE & GE(0) & GE(1) & GE(2) & GE(0) & GE(1) & GE(2) \\
\hline National & $\mathbf{2 1 . 3}$ & $\mathbf{2 7 . 9}$ & $\mathbf{4 7 . 5}$ & $\mathbf{2 6 . 5}$ & $\mathbf{2 9 . 3}$ & $\mathbf{4 1 . 3}$ \\
\hline Urban & 25.6 & 29.2 & 41.6 & 22.0 & 23.1 & 29.4 \\
\hline Rural & 13.5 & 14.0 & 45.1 & 17.9 & 22.7 & 38.9 \\
\hline Within-group inequality & 13.2 & 20.1 & 39.6 & 19.9 & 23.0 & 35.1 \\
\hline Between-group inequality & 8.0 & 7.9 & 7.9 & 6.6 & 6.3 & 6.2 \\
\hline Between as a share of total & 37.8 & 28.1 & 16.6 & 24.8 & 21.5 & 15.0 \\
\hline
\end{tabular}

Figure 12 . Income inequality

Source: HIES data, 2012. 
The analysis of the income inequality and its sources can be summarized as rural areas achieved growth based on new income sources such as non-farm self-employment income, salaried wages and remittances from abroad in the 1990s, but the extremely poor could not be benefited from those new income sources. Therefore, inequalities have increased in rural areas throughout these years. In urban areas, the extremely poor are unable to fully access to new income sources such as non-farm self-employment income, salaried wage, and remittances from abroad and rental value of housing. Further, nearly all antipoverty programs including human capital development programs and essential health service packages have been targeting to rural areas only.

\section{Unemployment Scenery}

The daily Star reported on a title "More People earning Their Own Livelihood Their Own Livelihoods Now" that the number of people dependent on others for livelihood went down by 11 percentage points in the last four years, thanks to their increasing participation in the economy, a new survey found ( the daily star.bd.com) . The national dependency ratio stood at 56 percent in 2012, down from 67 percent in 2008, said the Bangladesh Bureau of Statistics (BBS-2012). The survey showed that almost equal numbers of people were employed in jobs in rural and urban areas in the same period. However, a significant number of people are still relying on the breadwinners of their families to make a living.

About 61 percent of the rural population were still dependent on others to survive in 2012, which was 72 percent in 2008. The dependency rate in urban areas was 48 percent in 2012, from 59 percent in 2008 , according to the state-run statistical agency. The dependency ratio is an age-population ratio of those typically not in the labour force and those typically in the labour force. It is used to measure the pressure on productive population. The BBS survey showed the size of household also went down, from 4.7 persons per household in 2008 to 4.5 persons in 2012.

\begin{tabular}{|l|c|c|}
\hline \multicolumn{3}{|c|}{} \\
\hline DEPENDENCY RATIO IN \% & 2012 & 2008 \\
\hline National & 56 & 67 \\
\hline Rural & 61 & 72 \\
\hline Urban & 48 & 59 \\
\hline SOURCE OF LIGHT IN \% & 2012 & 2008 \\
\hline Kerosene & 33.1 & 47 \\
\hline Electricity & 65.6 & 53 \\
\hline MIGRATION & 2012 & 2008 \\
(PER 1,OOO POPULATION) & & \\
\hline Rural to urban & 26.6 & 17.3 \\
\hline Urban to urban & 43.5 & 34.4 \\
\hline
\end{tabular}

Figure 13. Unemployment Scenery

Source: The Daily Star.net.bd-dated 16.11.2014

Although the gradual economic expansion in the last three decades has added millions of women to the labour force, the number of women leading the households is still very low: 85.5 percent of the households were led by males in 2012, which was 89.3 percent in 2008. According to the latest survey, the number of people with access to electricity increased by more than 12 percentage points to 65.6 percent in 2012 from 2008, thanks to the government's special attention on the power sector, which saw both generation capacity and production double in the last six years. 
The survey also showed that internal migration is increasing: it was 40.2 persons per 1,000 in 2012 , from 30.6 in 2008. The urban centres are facing huge pressure when it comes to migration, as 26.2 people per 1,000 entered the cities in search of better employment opportunities and livelihoods, from 17.3 people per 1,000 in 2008. There was also a major shift in urban-to-urban migration: 43.5 persons among 1,000 people moved to new urban centres in 2012, which was 34.4 in 2008. The rural-to-rural migration was also on the rise, perhaps because of national disasters and river erosions which forced a lot of people in the coastal and char areas to move to other areas in search of jobs every year. According to the survey, the number of population in the country was 15.27 crore in 2012, with annual population growth rate standing at 1.36 percent, from 1.39 percent in 2008 . More than 41 percent of the population lived in urban areas, nearly five percentage points more than in 2008

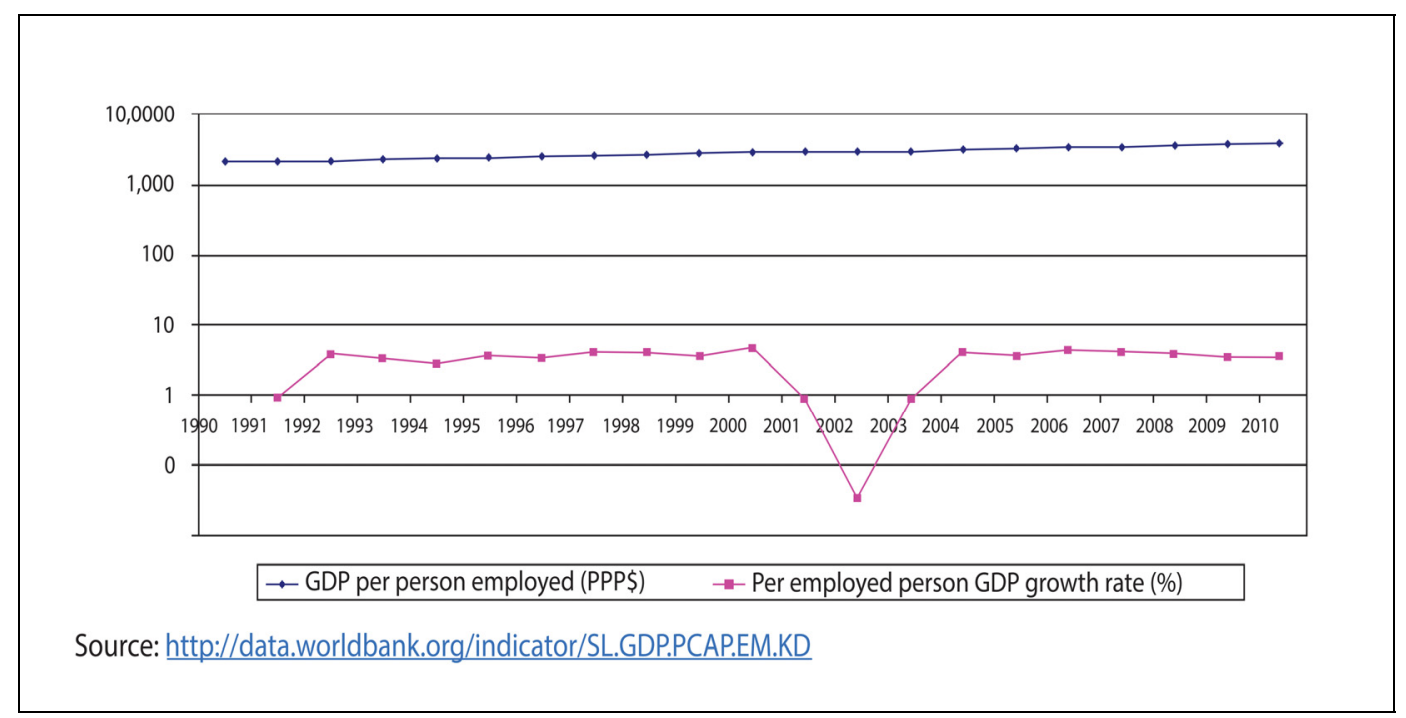

Figure 14. Trends of GDP per person employed, 1990-2010 period

The world Bank said information relating to growth rate of GDP per person employed is not available from the National Accounts Statistics of the BBS. However, from the World Bank data, it is observed that the GDP per person employed (constant 1990 PPP dollar) in Bangladesh was \$ 3,917 (PPP) in 2010 with a yearly growth rate of 3.43 percent. The GDP per person employed (PPP\$) with the growth rate is shown in Figure 2.8. It is observed that, the growth of GDP per person employed has been, on an average, 4.04 percent per year, over the last two decades or so. This matches more or less with per capita GDP growth during the 2001-2010 period. It is also observed that while GDP per person employed (PPP\$) displays slight upward trend over the 1991-2010 period, per employed person GDP growth rate show considerable fluctuations, with sudden dip during the 2002-2003 (the world bank, 2010).

\begin{tabular}{|l|c|c|c|}
\hline \multirow{2}{*}{} & \multicolumn{3}{|c|}{ \% among population aged 15 \& above } \\
\cline { 2 - 4 } & All & Male & Female \\
\hline $1990-1991$ & 51.2 & 86.2 & 14.0 \\
\hline $1995-1996$ & 52.0 & 87.0 & 15.8 \\
\hline $1999-2000$ & 54.9 & 84.0 & 23.9 \\
\hline $2002-2003$ & 57.3 & 87.4 & 26.1 \\
\hline $2005-2006$ & 58.5 & 86.8 & 29.2 \\
\hline 2010 & 59.3 & 82.5 & 36.0 \\
\hline
\end{tabular}

Source: Labour Force Survey,various years,BBS

Figure 15. Labour force participation rate, 1990-2010 
The latest available data based on the Labour Force Survey 2010 reveal that as of 2010, only 59.3 percent (56.7 million) of the population over 15 years of age was economically active. The participation rate of women which has been steadily increasing over the last two decades (1990-2010) is still quite low at 36 percent. The returns from labour force participation rates for female wage earners are lower than those of males, which partially explain their low participation rate. The annual rates of labour force and employment growth have also been rather low and women have contributed more to the annual increment of such growth compared to men.

\section{Conclusion}

Despite an impressive social and economic development in recent years, Bangladesh is still facing many complex short and long-term political and developmental challenges. Danida reported overall poverty levels fell from 57 percent in 1991-92 to 31.5 percent in 2010. The rate of reduction has been faster in the present decade compared with the last decade, lifting out of poverty more than 2.8 million people a year. Bangladesh is, however, still among the poorest countries in the world, ranking 146 out of 187 on the 2011 United Nations Human Development Index. Inequality is growing and many people are not benefiting from social and economic development. About 25 percent (40 million people) are extremely poor and spend almost all of their income on food and still do not meet their minimum nutritional requirements. Women, children and in particularly female headed households and children living without parental care are especially vulnerable. Around 40 percent of children and 30 percent of women are malnourished (http://um.dk/en/danida-en/goals/country). Minority ethnic groups also suffer from high levels of extreme poverty, particularly in regions such as the Chittagong Hill Tracts, the Northern Plains, Mymensingh and Cox's Bazaar (where there is a large population of Rohingya refugees from Myanmar). Poverty is monitored by, among others, UNDP, e.g. in connection with the reporting on the Millennium Development Goals. The World Bank (2002) found that there is consensus in Bangladesh on the important developmental priorities and challenges confronting the country. Among the major issues that different stakeholders identified during consultations recently commissioned by the government included: lack of physical infrastructure, law and order, organized crime, extortions and economic violence, lack of effective local government and decentralization, quality of education, health, and other social services, lack of coordination among development agencies and institutions, lack of remunerative employment and economic opportunities, lack of social capital at the community level, resulting in low-level of collective action, and lack of democratization of political process should be given more priority to reduce the poverty in Bangladesh.

\section{References}

Alcock, P. (1993). Understanding Poverty. Basingstoke: McMillan.

Aliber, M. (2001). Study of the Incidence and Nature of Chronic Poverty and Development Policy in South Africa: An Overview. Programme for Land and Agrarian Studies, School of Government, University of the Western Cape, South Africa. Retrieved from https://papers.ssrn.com/sol3/papers.cfm?abstract_id=1754544

Atkinson, Ab., \& Hills, J. Eds. (1998). Exclusion, Employment and Opportunity. Retrieved from http://www.gsdrc.org/document-library/social-exclusion-poverty-and-unemployment

Bangladesh Economic Review. 2005.

Bangladesh Economic Review. 2008.

Bangladesh Economic Review. 2010.

Bangladesh Economic Review. 2013.

BBS- Bangladesh Bureau of Statistics. (2010). Report of the Household Income and Expenditure Survey 2000. Dhaka: Government of Bangladesh.

BBS-Bangladesh Bureau of Statistics. (2003). Report of the Household Income and Expenditure Survey 2000. Dhaka: Government of Bangladesh. Retrieved https://www.google.com/search?q=Report+of+the+Household+Income+and+Expenditure+Survey

Clasen, J., \& Sinfield, A. Eds. The Sociology of Social Security. Edinburgh, Edinburgh University Press, pp.35-69. Retrieved from https://www.google.com/search?q=Clasen $\% 2 \mathrm{C}+\mathrm{J} .+$ and + Sinfield $\% 2 \mathrm{C}+\mathrm{A} .+$ Eds.The + Sociology + of + Social + Security.Edinburgh $\% 2 \mathrm{C}+$ Edinburgh+University + Press $\% 2 \mathrm{C}+\mathrm{pp} 3$

David Gordon. (1977). Definitions of Concepts for the Perceptions of Poverty and Social Exclusion Damned Whores and God's Police. Penguin.

Gordon, D., \& Spicker, P. (1998). The International Poverty Glossary. Zed Books, in press. 
Gordon, D., Levitas, R., Pantazis, C., Patsios, D., Payne, S., Townsend, P., .. Williams, J. (2000). Poverty and Social Exclusion in Britain. York: Joseph Rowntree Foundation. Retrieved from https://www.google.com/search?q=Gordon\%2C+D\%2C+Levitas\%2C+R\%2C+Pantazis2000.+Poverty+and + Social+Exclusion+in+Britain. + York

Gordon, D., Pantazis, C., \& Townsend, P. (1999). Changing Necessities of Life: 1983 to 1999. Working Paper No. 3. Townsend Centre for International Poverty Research: University of Bristol

Household Income Expenditure Survey. (2010). Retrieved from $\mathrm{http}: / /$ www.encyclopedia.com/topic/Culture_of_Poverty.aspx

Jim Masters. (2002). Poverty Knowledge: Social Science, Social Policy and the Poor in Twentieth-Century U.S. History, by Alice O' Conner January 11, 2002. Retrieved from https://www.google.com/search?q=Jim+Masters+\%2C2002+Poverty+Knowledge\%3A+Socia 1+Science

Karl Marx. (1976). The German Ideology. Moscow, p. 41. Originally published in Socialist Review Australian, Issue 2, Winter 1990, pp. 5-33.

Lewis, Oscar. (1959). Five Families: Mexican Case Studies in the Culture of Poverty. New York: Basic Books. Retrieved from https://www.google.com/search?q=Lewis\%2C+Oscar.+1959.+Five+Families\%3A+Mexican+Case+Studies + in + the + Culture + of + Poverty. + New + York

Lister, R. (forthcoming). Poverty. London: Polity Press.

M. Syeed Ahamed And Mohammad Ehsan. (2005). Bangladesh's Poverty Reduction Strategy: An Analysis from The Labour Market Perspective.

Michael, et al. (2004). Center for the analysis of South African social policy. Oxford University.

Millennium Development Goals: Bangladesh progress report 2010. Government of Bangladesh and the United Nations Country Team in Bangladesh. Dhaka: Government of Bangladesh.

Millennium Development Goals: Bangladesh progress report 2012. Government of Bangladesh and the United Nations Country Team in Bangladesh. Dhaka: Government of Bangladesh. Retrieved from https://www.google.com/search?q=Millennium+Development+Goals\%3A+Bangladesh+progress + report +2 012

Millennium Development Goals: Bangladesh progress report 2014. Government of Bangladesh and the United Nations Country Team in Bangladesh. Retrieved from Dhaka:.https://www.google.com/search?q=Millennium+Development+Goals\%3A+Bangladesh + progress $+\mathrm{r}$ eport +2014

Miriam Dixson. (1976). The Real Matilda. Penguin, Ringwood.

Rowntree, S. (1901). Poverty: a Study of Town Life. Macmillan: London.

Rubena Sukaj. (2012). American University and World Bank Priority Areas for Bangladesh's Further Development: Inequality, Employment, and Poverty.

S. Aminul Islam. (2004). Overcoming poverty in Bangladesh: Search for a new paradigm. Retrieved from https://www.google.com/search?q=Professor.S.AminulIslam2004.Overcoming+poverty+in+Bangladesh

Sandra Bloodworth. (1990). The Poverty of Patriarchy Theory.

Sen, Ak. (1983). Poor Relatively Speaking. Oxford Economic Papers. New Series, 35(2), 153-169.

Sen, Ak. (1985). Commodities and Capabilities. Amsterdam: North-Holland.

Sen, Ak. (1997). On Economic Inequality. Oxford: Clarendon.

Sen, Ak. (1999). Development is Freedom. Oxford: OUP.

Sen, Binayek, \& Atiur Rahman. (1999). Face of Human Poverty: South Asia Monitor. Dhaka: BIDS (mimeo, draft).

Retrieved

from https://www.google.com/search?q=Sen\%2C+Binayek+and+Atiur+Rahman.1999.Face

Sen, Binayek. (2003). Drivers of Escape and Descent: Changing Household Fortunes in Rural Bangladesh. World Development, 31(3), 513-534.

Townsend, P. (1979). Poverty in the United Kingdom. Harmondsworth, Penguin. 
Townsend, P. (1996). A Poor Future: Can We Counteract Growing Poverty in Britain and across the World. London, Lemos and Crane. Retrieved from https:/www.google.com/search?q=Townsend\%2C+P.+1996+A+Poor+Future\%3A+Can+we+Counteract+ Growing+Poverty+in+Britain

Townsend, P., \& Abel-Smith, B. (1965). The Poor and the Poorest. London: Bell.

Townsend, P., \& Gordon, D. (1989). Low Income Households. Memorandum of Evidence to the House of Commons Social Services Committee, 579, 45-73. (Also published as Townsend, P. and Gordon, D. 1991 What is Enough? New Evidence on Poverty Allowing the Definition of a Minimum Benefit, In Alder, M., Bell C.,

Townsend, P., Gordon, D., Bradshaw, J., \& Gosschalk, B. (1997). Absolute and Overall Poverty in Britain in 1997: What the Population Themselves Say: Bristol Poverty Line Survey. Statistical Monitoring Unit Report No. 8, University of Bristol.

Vylder, Stefan de. (1982). Agriculture in Chains: Bangladesh: A Case Study in Contradictions and Constraints. London: Zed.

Walder, Andrew G. (1995). Local Governments as Industrial Firms: An Organizational Analysis of China's Transitional Economy. American Journal of Sociology, 101(2), 263-301.

World Bank World Bank. (2002b). Poverty and Vulnerability in South Asia. Washington, D.C.

World Bank. (1990). World Development Report 1990. New York: Oxford University Press.

World Bank. (1998). Bangladesh: From Counting the Poor to Making the Poor Count. Dhaka.

World bank. (2002). Poverty in Bangladesh: Building on Progress.

World Bank. (2002a). Globalization, Growth, and Poverty. Washington, D.C.

World Bank. (2002c). The World Bank Perspectives on Development 2001/2002. Sussex: Creative Communication $\quad$ Group. $\quad$ Retrieved from https://www.google.com/search?q=World+Bank.2002c. The+World+Bank+Perspectives+on+Development $+2001$

World Bank. 2014

World Bank.2014

World Development Report 2000. New York: Oxford University Press.

www.encyclopedia.com

\section{Copyrights}

Copyright for this article is retained by the author(s), with first publication rights granted to the journal.

This is an open-access article distributed under the terms and conditions of the Creative Commons Attribution license (http://creativecommons.org/licenses/by/4.0/). 